\title{
A multiple electrolyte concept for lithium-metal batteries
}

Daniele Di Lecce, ${ }^{[a, b]}$ Varvara Sharova, ${ }^{[a, b]}$ Sangsik Jeong, ${ }^{[a, b]}$ Arianna Moretti, ${ }^{[a, b]}$ Stefano

$$
\text { Passerini*[a, b] }
$$

Helmholtz Institute Ulm (HIU), Helmholtzstraße 11, 89081, Ulm, Germany

Karlsruhe Institute of Technology (KIT), P.O. Box 3640, 76021, Karlsruhe, Germany

*Corresponding author: stefano.passerini@kit.edu

\section{Keywords}

(Fluorosulfonyl)(trifluoromethanesulfonyl)imide; Ionic liquid; N-methoxyethyl-Nmethylpyrrolidium; Poly (ethylene oxide); Polymer electrolyte; $\mathrm{LiFePO}_{4}$.

\section{Highlights}

- A cross-linked ternary electrolyte with novel composition is investigated.

- The electrolyte is formed by poly(ethylene oxide), Pyr ${ }_{1201}$ FTFSI and LiFTFSI.

- The electrolyte has promising thermal and electrochemical properties.

- $\mathrm{Li} / \mathrm{LiFePO}_{4}$ cells exhibit suitable performance at $40{ }^{\circ} \mathrm{C}$.

- Preliminary results suggest possible application at $20^{\circ} \mathrm{C}$.

\begin{abstract}
A cross-linked polymer membrane formed by poly(ethylene oxide) (PEO), Nmethoxyethyl-N-methylpyrrolidium (fluorosulfonyl)(trifluoromethanesulfonyl)imide (Pyr ${ }_{1201}$ FTFSI) ionic liquid and LiFTFSI salt is proposed as the electrolyte for lithium-metal batteries. The ternary membrane has a PEO:Pyr ${ }_{1201}$ FTFSI:LiFTFSI composition of 20:6:4 by mole, which ensures thermal stability up to $220^{\circ} \mathrm{C}$, overall ionic conductivity of $10^{-3} \mathrm{~S} \mathrm{~cm}^{-1}$
\end{abstract}


at $40{ }^{\circ} \mathrm{C}$ and suitable $\mathrm{Li}^{+}$transport properties. Combined with the $\mathrm{LiFePO}_{4}$ composite electrode, whose pores are filled with the Pyr ${ }_{1201}$ FTFSI:LiFTFSI electrolyte, and Li metal anode, it yields $\mathrm{Li} / \mathrm{LiFePO}_{4}$ cells delivering at $40{ }^{\circ} \mathrm{C}$ stable capacity $\left(150 \mathrm{mAh} \mathrm{g}^{-1}\right.$ or $\left.0.7 \mathrm{mAh} \mathrm{cm}^{-2}\right)$ with coulombic efficiency higher than $99.5 \%$. Impedance spectroscopy measurements reveal low resistance of the electrode/electrolyte interface at both the anode and the cathode. Preliminary results at $20^{\circ} \mathrm{C}$ indicates a capacity of $130 \mathrm{mAh} \mathrm{g}^{-1}$ at $\mathrm{C} / 10$ rate $\left(17 \mathrm{~mA} \mathrm{~g}^{-1}\right)$ with coulombic efficiency higher than $99.5 \%$, thereby suggesting PEO:Pyr ${ }_{1201}$ FTFSI:LiFTFSI as suitable electrolyte for lithium-metal polymer batteries for stationary storage applications, coupled for example with PV and wind generation.

\section{Introduction}

Current lithium-ion batteries typically employ electrolyte solutions based on volatile and flammable alkyl carbonates, which may lead to safety issues due to possible uncontrolled exothermic reactions [1,2]. The risk of thermal runaways and fire accidents is, however, efficiently mitigated by conventional and advanced lithium-ion anodes [3,4]. Accordingly, the lithium-ion chemistry has been extensively used over the last 25 years. However, further investigation is in progress with the aim of enhancing cell performance, safety and reliability through the development of alternative chemistries and technology optimization [5]. In particular, a renewed interest towards the high-energy, lithium-metal anode has recently attracted the attention of the scientific community toward the research of effective strategies to decrease the hazards related to Li dendrite growth [6,7], which may lead to short circuit and, eventually, thermal runaway [1]. Thus, alternative electrolytes characterized by remarkable thermal stability and low flammability have been lately proposed with interesting results, involving ether compounds based on the ethylene oxide group (i.e., $\left.-\mathrm{O}\left(\mathrm{CH}_{2} \mathrm{CH}_{2} \mathrm{O}\right)_{n}{ }^{-}\right)[8-11]$, ionic liquids [12,13], and inorganic solid electrolytes [14-17]. Among them, solid polymer 
electrolytes (SPEs) based on poly(ethylene oxide) (PEO) have been widely investigated owing to their suitable thermal and electrochemical features [18].

PEO is a semi-crystalline polymer able to complex lithium salts ( $\mathrm{LiX})$, thus forming Li-ion conductive SPEs. Despite a few works reported lithium-ion conductivity in the crystalline phase, the $\mathrm{Li}^{+}$transport mainly occurs within the amorphous fraction through intraand inter-chain hopping mostly promoted by chain mobility above the glass transition temperature $\left(\mathrm{T}_{\mathrm{g}}\right)$. Accordingly, PEO-LiX complexes typically exhibit suitable conductivity (about $10^{-4} \mathrm{~S} \mathrm{~cm}^{-1}$ ) above the melting point of PEO $\left(\mathrm{T}_{\mathrm{m}} \approx 65^{\circ} \mathrm{C}\right)$ [19]. Several approaches have been attempted to enhance the lithium-ion transport below $60{ }^{\circ} \mathrm{C}$ and improve the electrode/electrolyte interface, such as the use of ceramic fillers [20,21] and liquid plasticizers [22-25]. In particular, the addition of ionic liquids (ILs) in PEO-based electrolytes can actually increase the ionic conductivity by favoring the chain mobility without drawbacks in terms of safety. Therefore, ternary PEO-IL-LiX electrolytes typically show suitable electrochemical features below $60{ }^{\circ} \mathrm{C}$ and remarkable thermal stability [26]. However, such a performance enhancement is usually associated with poor mechanical properties with respect to pristine PEO-LiX electrolytes. This issue has been efficiently addressed by chemical cross-linking within the PEO matrix [27,28], thus forming cross-linked ternary polymer electrolytes (clTPEs), which combine remarkable thermal stability, good mechanical properties, large amorphous fraction, and high conductivity at relatively low temperature. The slow ion transport at room temperature with respect to conventional carbonate-based electrolytes is presently the main disadvantage of alternative solutions based on ILs and PEO. In this respect, a new ILbased electrolyte formed by N-methoxyethyl-N-methylpyrrolidium (fluorosulfonyl)(trifluoromethanesulfonyl)imide $\quad$ (Pyr $\left.\mathrm{Py}_{1201} \mathrm{FTFSI}\right) \quad$ and $\quad$ lithium (fluorosulfonyl)(trifluoromethanesulfonyl)imide (LiFTFSI) in the 6:4 molar ratio has been recently proposed for application in lithium battery. This particular composition, characterized 
by high lithium concentration, led to improved performance at room temperature compared to the diluted solution, demonstrating suitable cycling in lithium and lithium-ion cells [29]. Therefore, following this trend, we report herein the study of a cl-TPE formed by PEO, $\operatorname{Pyr}_{1201}$ FTFSI and LiFTFSI in the molar ratio of 20:6:4. The electrolyte was easily prepared by a hot-pressing procedure and cross-linked with benzophenone through UV irradiation. The thermal and electrochemical properties of the cl-TPE were investigated in order to evaluate the suitability of the system in lithium-metal battery working below $60{ }^{\circ} \mathrm{C}$. Hence, Li/clTPE/ $\mathrm{LiFePO}_{4}$ cells characterized by appealing features for the development of safe energy storage technology were realized, taking advantage of the mechanical stability of the crosslinked polymer electrolytes, which allows the electrode porosity filling with the conductive $\operatorname{Pyr}_{1201}$ FTFSI:LiFTFSI liquid electrolyte.

\section{Experimental}

Poly(ethylene oxide) (PEO, $\mathrm{M}_{\mathrm{v}}=100,000$, Sigma-Aldrich) and benzophenone (for synthesis, $\geq 99.0 \%$, Merck) were dried under vacuum for $48 \mathrm{~h}$ at $50{ }^{\circ} \mathrm{C}$ and room temperature, respectively. Pyr $_{1201}$ FTFSI was synthesized by direct alkylation of $\mathrm{N}$-methylpyrrolidine with 2-bromoethyl methyl ether ( $>95 \%$, TCI Japan) followed by anion exchange with FTFSI in aqueous solution, as previously reported [30,31]. Both LiFTFSI (Provisco CS Ltd, Czech Republic) and $\mathrm{Pyr}_{1201}$ FTFSI were dried by a turbo-molecular pump at room temperature until the final pressure was about $10^{-7}$ mbar.

The ternary polymer electrolyte (TPE) was prepared by hot-pressing a mixture of PEO, $\mathrm{Pyr}_{1201}$ FTFSI, and LiFTFSI in the molar ratio 20:6:4. Benzophenone (2 wt.\% of PEO) was also added into the mixture to make the cross-linked TPE (cl-TPE), which was cross-linked by UV irradiation [32]. In details, benzophenone was dissolved in $\mathrm{Pyr}_{1201}$ FTFSI when needed, while LiFTFSI and PEO were gently mixed in an agate mortar. Afterwards, the ionic liquid solution was added to the solid powder. The resulting mixture was hand-mixed through a spatula until 
formation of a paste, which was sealed under vacuum in an aluminum-foil pouch and annealed overnight at $60{ }^{\circ} \mathrm{C}$. The annealed mixture was then sandwiched between two Mylar foils (PPI) and hot-pressed at $60{ }^{\circ} \mathrm{C}$ using a Servitec Polystat 200T hydraulic press to obtain a film of thickness below $100 \mu \mathrm{m}$. When needed, the electrolyte film was irradiated in a UV chamber (Uvacuve 100) for 6 min ( 3 min each side). The liquid electrolyte solution was made by mixing $\operatorname{Pyr}_{1201}$ FTFSI and LiFTFSI (both pre-dried by turbo-molecular pump) in the $6: 4$ molar ratio [29]. The resulting liquid solution was dried 2 days by turbomolecular pump. The electrolytes preparation was carried out in a dry room (dew point $\left.<-70^{\circ} \mathrm{C}\right)$.

Thermogravimetric analysis (TGA) was performed through a TG209 F1 Libra Netzsch instrument, heating the samples from 30 to $600{ }^{\circ} \mathrm{C}$ at a rate of $5{ }^{\circ} \mathrm{C} \mathrm{min}-1$ under a nitrogen flow $\left(40 \mathrm{~mL} \mathrm{~min}^{-1}\right)$. The samples were hermetically sealed inside a dry room (dew point $<-70{ }^{\circ} \mathrm{C}$ ) in $\mathrm{Al}$ crucibles, which were punched by the TGA instrument under the $\mathrm{N}_{2}$ atmosphere just before the measurement. Differential scanning calorimetry (DSC) was carried out by using a Discovery DSC, TA Instruments Q2000, with liquid $\mathrm{N}_{2}$ cooling. DSC scans were performed in a nitrogen atmosphere at a rate of $10^{\circ} \mathrm{C} \mathrm{min}^{-1}$. The samples were sealed in $\mathrm{Al}$ pans inside a dry room (dew point $<-70{ }^{\circ} \mathrm{C}$ ) and cycled between $50{ }^{\circ} \mathrm{C}$ and $-140{ }^{\circ} \mathrm{C}$ at $10{ }^{\circ} \mathrm{C} \mathrm{min}^{-1}$ before performing the measurement.

Ionic conductivity was evaluated by electrochemical impedance spectroscopy (EIS) on a $\mathrm{Cu} / \mathrm{cl}-\mathrm{TPE} / \mathrm{Cu}$ pouch cell at several temperatures. The cell was assembled in a dry room (dew point $\left.<-70{ }^{\circ} \mathrm{C}\right)$ by using $\mathrm{Cu}$ foils $(50 \mu \mathrm{m}$, Schlenk) of $2 \times 2 \mathrm{~cm}$ size as electrodes. The temperature was controlled by a Binder climatic chamber. Each spectrum was recorded after $24 \mathrm{~h}$ of temperature equilibration. EIS was performed through an Impedance/Gain Phase Analyzer 1260, Solartron Analytics, using a $10 \mathrm{mV}$ amplitude signal in the $100 \mathrm{kHz}-10 \mathrm{~Hz}$ frequency range. 
The limiting current density was measured at $40{ }^{\circ} \mathrm{C}$ by linear sweep voltammetry at a scan rate of $0.01 \mathrm{mV} \mathrm{s}^{-1}$ of a $\mathrm{Li} / \mathrm{cl}-\mathrm{TPE} / \mathrm{Li}$ coin cell, performed through a VMP3, Biologic Science Instruments. The anodic stability window of the electrolyte was determined by a linear sweep voltammetry test at $40^{\circ} \mathrm{C}$ at a scan rate of $0.1 \mathrm{mV} \mathrm{s}^{-1}$ of a coin cell using lithium metal as the counter electrode and carbon-coated $\mathrm{Al}$ as the working electrode, which was performed through a VMP3, Biologic Science Instruments. The carbon-coated electrode was prepared by casting a slurry of conductive carbon (Super C45, Cnergy) and sodium carboxymethyl cellulose (Walocel CRT) binder in the 80:20 weight ratio in ultrapure water on an aluminum foil through doctor blade. The resulting film was dried at $80{ }^{\circ} \mathrm{C}$ in an oven for about $15 \mathrm{~min}$ and then dried $6 \mathrm{~h}$ at $180^{\circ} \mathrm{C}$ under vacuum.

The resistance at the lithium/electrolyte interface $\left(\mathrm{R}_{\mathrm{i}}\right)$ was evaluated by EIS on a Li/clTPEs/Li coin cell during storage at $40{ }^{\circ} \mathrm{C}$ for 30 days. EIS was performed through an Impedance/Gain Phase Analyzer 1260, Solartron Analytics, by applying a $10 \mathrm{mV}$ amplitude signal in the $200 \mathrm{kHz}-0.1 \mathrm{~Hz}$ frequency range. The EIS data were analyzed by nonlinear least squares (NLLS) method using the Boukamp software [33,34]. The lithium stripping-deposition test was carried out at $40{ }^{\circ} \mathrm{C}$ using a $\mathrm{Li} / \mathrm{cl}-\mathrm{TPE} / \mathrm{Li}$ coin cell, by galvanostic cycling through a Maccor 4300 Battery tester with a current of $100 \mu \mathrm{A} \mathrm{cm}^{-2}$ and a time step of $1 \mathrm{~h}$.

The $\mathrm{LiFePO}_{4}$ (Clariant) electrode film was prepared by mixing active material, conductive carbon (Super C45, Cnergy), and sodium carboxymethyl cellulose (Walocel CRT) binder in the 88:7:5 weight ratio in ultrapure water. The cathode slurry was cast on an aluminum foil by doctor blade. The resulting film was dried at $80{ }^{\circ} \mathrm{C}$ in an oven for about 15 min and then dried $6 \mathrm{~h}$ at $180{ }^{\circ} \mathrm{C}$ under vacuum. A further electrode tape was prepared through the same procedure by using active material, conductive carbon (Super C45, Cnergy), sodium carboxymethyl cellulose (Walocel CRT), and styrene-butadiene rubber (JSR Micro) in the 99:4:2:2 weight ratio and used for the rate capability test (see the Results and discussion 
section). The active material loading was $5.0 \pm 0.3 \mathrm{mg} \mathrm{cm}^{-2}$ and $2.6 \pm 0.1 \mathrm{mg} \mathrm{cm}^{-2}$ for the cycling tests at $40{ }^{\circ} \mathrm{C}$ and $20^{\circ} \mathrm{C}$, respectively.

Two-electrode 2032 coin cells were assembled in an Ar-filled glove box by using electrode disks with diameter of $14 \mathrm{~mm}$ and cl-TPE separators with diameter of $16 \mathrm{~mm}$. Before the polymer cell assembling, the cathodes were wet under vacuum with a few drops of $\operatorname{Pyr}_{1201}$ FTFSI:LiFTFSI 6:4 (mol/mol) electrolyte solution for about $40 \mathrm{~min}$. Galvanostatic cycling tests of $\mathrm{Li} / \mathrm{cl}-\mathrm{TPE} / \mathrm{LiFePO}_{4}$ cells were carried out through a Maccor 4300 Battery tester. The rate capability test was carried out at $40{ }^{\circ} \mathrm{C}$ by galvanostatic cycling at $\mathrm{C} / 20, \mathrm{C} / 10, \mathrm{C} / 5$, $\mathrm{C} / 3$, and $\mathrm{C} / 2$ rates $\left(1 \mathrm{C}=170 \mathrm{~mA} \mathrm{~g}{ }^{-1}\right)$ in the $2-3.9 \mathrm{~V}$ range. Two $\mathrm{Li} / \mathrm{cl}-\mathrm{TPE} / \mathrm{LiFePO}_{4}$ cells were tested at $40{ }^{\circ} \mathrm{C}$ using current rates of $\mathrm{C} / 10$ and $\mathrm{C} / 5$, respectively; the former was cycled in the $2-3.9 \mathrm{~V}$ range at constant current $(\mathrm{CC})$ while the latter was cycled in the $2-3.7 \mathrm{~V}$ range at $\mathrm{CC}$ using a constant voltage (CV) step at the end of charge (current limit for the CV step of $\mathrm{C} / 20$ rate). $\mathrm{Li} / \mathrm{cl}-\mathrm{TPE} / \mathrm{LiFePO}_{4}$ cells were cycled at $20{ }^{\circ} \mathrm{C}$ in the $2-4 \mathrm{~V}$ range using current rates of $\mathrm{C} / 10$ and $\mathrm{C} / 20$. The temperature was controlled by a Binder climatic chamber.

EIS measurements were carried out on a $\mathrm{Li} / \mathrm{cl}-\mathrm{TPE} / \mathrm{LiFePO}_{4}$ cell upon galvanostatic cycling at $40{ }^{\circ} \mathrm{C}$ with a $\mathrm{C} / 10$ rate $\left(1 \mathrm{C}=170 \mathrm{~mA} \mathrm{~g}^{-1}\right)$ within the $2-3.9 \mathrm{~V}$ range. Impedance spectra were recorded at the OCV, at state of charge (SOC) of $25 \%$ and $100 \%$, and state of discharge (SOD) of $25 \%$ and $100 \%$. Each EIS measurement was performed after 6 min of cell relaxation. The EIS-galvanostatic cycling experiment was carried out through a VMP3, Biologic Science Instruments. EIS was performed by using a $10 \mathrm{mV}$ amplitude signal in the 1 $\mathrm{MHz}-30 \mathrm{mHz}$ frequency range.

Further galvanostatic cycling tests at $20{ }^{\circ} \mathrm{C}$ of $\mathrm{Li} / \mathrm{LiFePO}_{4}$ cells using the liquid $\operatorname{Pyr}_{1201}$ FTFSI:LiFTFSI 6:4 (mol/mol) electrolyte were carried out through a Maccor 4300 Battery tester at $\mathrm{C} / 10, \mathrm{C} / 5, \mathrm{C} / 3, \mathrm{C} / 2$, and $1 \mathrm{C}$ rates $\left(1 \mathrm{C}=170 \mathrm{~mA} \mathrm{~g}^{-1}\right.$; active material loading of about $3.6 \pm 0.7 \mathrm{mg} \mathrm{cm}^{-2}$ ). Whatman glass fiber disks of $16 \mathrm{~mm}$ diameter soaked by the 
electrolyte were employed as the separators (see the Supplementary Information for further details).

\section{Results and discussion}

Fig. 1 reports the results of the thermal characterization of the electrolyte without benzophenone (TPE, blue curves) and cross-linked with benzophenone (cl-TPE, green curves) by UV irradiation (see the Experimental section for further details about sample preparation). TGA in inert atmosphere (Fig. 1a) reveals the same trend for both samples, characterized by a huge weight loss above $200{ }^{\circ} \mathrm{C}$ involving two steps, as further evidenced by the derivative curve dashed lines (referring to the right y-axis). The derivative maxima occur at $220{ }^{\circ} \mathrm{C}$ and $290^{\circ} \mathrm{C}$. Fig. S1a (Supplementary Information) also reports the TGA of LiFTFSI, Pyr ${ }_{1201}$ FTFSI and the LiFTFSI:Pyr ${ }_{1201}$ FTFSI solution (molar ratio of 6:4). This latter figure shows a dramatic weight loss at about $290^{\circ} \mathrm{C}$ for both $\mathrm{Pyr}_{1201}$ FTFSI and LiFTFSI:Pyr ${ }_{1201}$ FTFSI samples, while LiFTFSI exhibits a decomposition in a wide temperature range. Indeed, in agreement with literature data $[35,36]$, LiFTFSI starts to decompose below $200^{\circ} \mathrm{C}$, as clearly revealed by Fig. S1a inset, although the main weight loss occurs above $300^{\circ} \mathrm{C}$. Overall, the TPEs decomposition starts from that of LiFTFSI and ends with that of the IL-salt mixture.

Panels b and c of Fig. 1 show the cooling and heating scans, respectively, of the DSC measurements performed on the electrolyte samples. DSC reveals a glass transition at about $100{ }^{\circ} \mathrm{C}\left(\mathrm{T}_{\mathrm{g}}\right)$ in the TPE, which increases to $-90{ }^{\circ} \mathrm{C}$ for the cl-TPE (see Fig. $1 \mathrm{~b}$ and c). Also, the heating traces of all samples indicate a melting feature, starting at about $10^{\circ} \mathrm{C}$ (see Fig. $1 \mathrm{c}$ ). The melting temperature $\left(\mathrm{T}_{\mathrm{m}}\right)$ is $35{ }^{\circ} \mathrm{C}$ for the non-cross-linked electrolyte and slightly decreases to $30{ }^{\circ} \mathrm{C}$ after cross-linking. Besides the similar behavior in terms of glass transition and melting for all samples, DSC reveals that cross-linking has a remarkable effect on the crystallization. In fact, the TPE (blue curve) shows upon cooling an exothermic crystallization peak at about $10{ }^{\circ} \mathrm{C}\left(\mathrm{T}_{\mathrm{c}}\right)$, which starts at $30{ }^{\circ} \mathrm{C}$ (see Fig. 1b). On the other hand, no 
crystallization is observed in the DSC of the cl-TPE (compare the green and blue curves of Fig. 1b). Such a trend upon cooling is directly reflected into the exothermic peak at about $-40{ }^{\circ} \mathrm{C}$ upon heating (see Fig. 1c). This exothermic process, ascribed to a cold-crystallization, does not occur in the TPE, while it takes place in the cl-TPE. Therefore, the DSC behavior indicates that cross-linking likely slows down the crystallization kinetics, preventing the crystallization upon cooling at about $30^{\circ} \mathrm{C}$ and favoring an amorphous metastable phase at low temperatures. This behavior has been already observed in PEO-based, IL-containing ternary electrolyte [37]. Furthermore, the lower melting temperature and heat of fusion $(\Delta \mathrm{H})$ of the cl-TPE compared to the TPE ( $\triangle \mathrm{H}$ is $18.2 \mathrm{~J} \mathrm{~g}^{-1}$ and $16.6 \mathrm{~J} \mathrm{~g}^{-1}$ for the TPE and cl-TPE samples, respectively) suggest a slight increase of amorphous fraction after cross-linking, which is expected to have minor effects on the ion transport properties. However, possible effects of the particular DSC protocol herein employed and of the thermal history of the samples cannot be excluded [37].

Panels b and c of Fig S1 in the Supplementary Information also reports the DSC traces of LiFTFSI, Pyr ${ }_{1201}$ FTFSI and the $\operatorname{Pyr}_{1201}$ FTFSI:LiFTFSI solution $(6: 4 \mathrm{~mol} / \mathrm{mol})$. In agreement with literature reports [29], the figure shows a glass transition occurring at about 107 and $-76{ }^{\circ} \mathrm{C}$ in the $\operatorname{Pyr}_{1201}$ FTFSI and $\mathrm{Pyr}_{1201}$ FTFSI:LiFTFSI samples, while there is no evidence of crystalline phases within the whole investigated temperature range.

\section{Figure 1}

The cross-linking has proven to enhance the mechanical properties of TPEs, having a minor influence on the ionic conductivity in high-concentration samples [38]. In particular, two concurrent phenomena related to the cross-linking control the ion transport properties, namely

(i) the amorphous fraction increase, which increases the conductivity, and (ii) the decrease of chain mobility, which hinders the ions motion. The former effect is typically predominant in TPEs having low concentration of IL, while the latter may slightly affect the conductivity of TPEs having high concentration of IL and/or salt, which already show large amorphous fraction 
before the cross-linking [38]. Accordingly, high-concentration, cross-linked TPEs generally exhibit suitable conductivity and electrochemical behavior at relatively low temperature (below $60{ }^{\circ} \mathrm{C}$ ) as well as improved mechanical stability [27]. However, the cross-linking unavoidably decrease of chain mobility, leading to hindered ions motion, as shown by the ionic conductivity tests of Fig. S2 in the Supplementary Information (see the Supplementary Information for further details). The simple UV photo-irradiation technique allows to control the cross-linking fraction by changing the irradiation time. In particular, Kim et al. observed by solvent extraction tests on UV cross-linked PEO-Pyr ${ }_{14}$ TFSI-LiTFSI films a bell-shape behavior at increasing irradiation time, which has been attributed to photo-induced cross-linking and depolymerization. Accordingly, the cross-linking fraction follows a Gaussian-like trend for irradiation times from 7 to 14 min, with maximum and minimum values of about 80 and $90 \%$, respectively [27]. Herein, the electrochemical properties of the cl-TPE sample have been studied by combining impedance spectroscopy and linear sweep voltammetry tests. Fig. 2 reports the related results in terms of ionic conductivity, limiting current density in lithium cell and anodic stability window. The ionic conductivity of the cl-TPE has been investigated by EIS on a blocking-electrode cell within the temperature range from 0 to $80{ }^{\circ} \mathrm{C}$ (see Fig. $2 \mathrm{a}$ ). Impedance spectra have been recorded every $10{ }^{\circ} \mathrm{C}$ after $24 \mathrm{~h}$ of temperature equilibration. The conductivity has been measured upon heating and cooling scans in order to detect possible kinetics effects related to the formation of metastable phases (see the Experimental section for further details).

The cl-TPE has ionic conductivity of the order of $10^{-4} \mathrm{~S} \mathrm{~cm}^{-1}$ at $0{ }^{\circ} \mathrm{C}$, increasing to about $4 \times 10^{-3} \mathrm{~S} \mathrm{~cm}^{-1}$ at $80^{\circ} \mathrm{C}$. As mentioned above, the cross-linking has an adverse effect on the ionic conductivity, which is predominant at low temperature (see new Fig. S2 in the Supplementary Information). This phenomenon, attributed to hindered chain mobility due to the cross-linking, has been already observed in the literature for IL-containing, PEO-based 
TPEs having high salt concentration [38]. The cl-TPE electrolyte shows an ionic conductivity of about $2 \times 10^{-3} \mathrm{~S} \mathrm{~cm}^{-1}$ at $40^{\circ} \mathrm{C}$, which is a suitable value for electrochemical applications. Accordingly, such a temperature value is proposed as the optimal compromise ensuring suitable transport properties. However, it is worth mentioning that the actual maximum current occurring in a practical lithium cell is attributed to the net $\mathrm{Li}^{+}$flow through the electrolyte, while the ionic conductivity determined by EIS is related to the mobility of all charge carriers, i.e., the $\mathrm{Pyr}_{12 \mathrm{O} 1^{+}}, \mathrm{Li}^{+}$and $\mathrm{FTFSI}^{-}$ions and various ion triplets. Therefore, the limiting current density ( $\left.\mathrm{i}_{\mathrm{lim}}\right)$ of the electrolyte in lithium battery has been estimated by performing a linear sweep voltammetry test in $\mathrm{Li} / \mathrm{Li}$ symmetrical cell. This measurement and the further electrochemical characterization of the electrolyte have been carried out at $40{ }^{\circ} \mathrm{C}$. The results, shown in Fig. 2b, reveal a steep current rise followed by a plateau, which indicates the maximum current allowed by the $\mathrm{Li}^{+}$motion within the electrolyte, that is the limiting current,

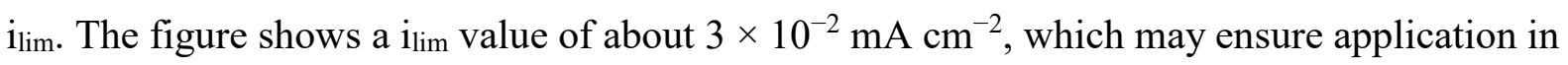
lithium cells operating at low current.

\section{Figure 2}

The anodic stability window of the electrolyte has been determined by linear sweep voltammetry in a lithium cell using a carbon-based working electrode (see Fig. 2c and the Experimental section for further details). Accordingly, the experiment shows the electrochemical processes due to the electrolyte reaction on the composite electrode film, thereby reasonably reproducing the electrolyte behavior on the composite $\mathrm{LiFePO}_{4}$ cathode. It is noteworthy that the anodic stability window of the electrolyte might be underestimated in tests with Ni or Pt working electrodes. Fig. 2c shows a dramatic current increase due to the electrolyte oxidation above $4.2 \mathrm{~V}$, indicating large electrolyte oxidation. Furthermore, nonnegligible currents are measured below $4.2 \mathrm{~V}$. Thus, the current flow at $3.9 \mathrm{~V}$ is about $3 \mu \mathrm{A}$ $\mathrm{cm}^{-2}$, and increases to $11 \mu \mathrm{A} \mathrm{cm}{ }^{-2}$ at $4.1 \mathrm{~V}$, in agreement with literature reports on PEO-based 
electrolytes [39]. Such a current is likely attributed to minor electrolyte oxidation and formation of the electrode/electrolyte interface film. Accordingly, the voltage cutoff of the galvanostatic cycling tests at $40{ }^{\circ} \mathrm{C}$ (see the following section) was set at $3.9 \mathrm{~V}$ in order to ensure reversible operation of the $\mathrm{LiFePO}_{4}$ material at about $3.45 \mathrm{~V}_{\text {vs. }} \mathrm{Li}^{+} / \mathrm{Li}[40]$ and negligible electrolyte oxidation.

As for the anode side, the Li/cl-TPE interface has been studied under static and dynamic conditions by combining EIS and galvanostatic cycling in $\mathrm{Li} / \mathrm{Li}$ symmetrical cells. Accordingly, panels a and b of Fig. 3 report the Li/cl-TPE interface resistance $\left(\mathrm{R}_{\mathrm{i}}\right)$ trend during cell storage at $40{ }^{\circ} \mathrm{C}$ and the voltage profiles related to a lithium stripping-deposition test, respectively. $\mathrm{R}_{\mathrm{i}}$ has been evaluated by NLLS fitting $[33,34]$ of EIS data. Inset of Fig. 3a reports the Nyquist plot of the EIS measurements and the equivalent circuit employed for the NLLS fitting (see the Experimental section for further details). The cell exhibits a high-middle frequency semicircle attributed to the processes at the lithium/electrolyte interface and a low frequency diffusion feature (see Fig. 3a inset). The Li/cl-TPE interface has an initial $\mathrm{R}_{\mathrm{i}}$ of about $34 \Omega \mathrm{cm}^{-2}$, which increases to $72 \Omega \mathrm{cm}^{-2}$ after 3 days of storage. Then, the interface resistance grows up to about $100 \Omega \mathrm{cm}^{-2}$ during the first 10 days (see Fig. 3a). The experiment reveals gradual cell stabilization after the first 10 days: indeed, $R_{i}$ slightly increases throughout the following 10 days (from the $10^{\text {th }}$ to the $20^{\text {th }}$ day) up to a stable value of about $120 \Omega \mathrm{cm}^{-2}$. The test suggests the gradual growth of a solid electrolyte interphase (SEI) over the lithium-metal electrode and its following stabilization after 20 days of cell storage [41]. This value is significantly lower than those reported for similar IL-containing polymer electrolytes $[27,32,42]$, thereby suggesting improved interfacial properties of the proposed cl-TPE with the lithium metal electrode. As for the interface behavior under dynamic condition, the voltage profile of the cycling test at $100 \mu \mathrm{A} \mathrm{cm}^{-2}$ (Fig. 3b) reveals an initial overvoltage of about 70 
$\mathrm{mV}$, increasing to about $150 \mathrm{mV}$ after 55 days. Thus, the cl-TPE ensures relatively low interface resistance with lithium metal and reversible plating-stripping upon prolonged cycling.

\section{Figure 3}

In summary, the results suggest the cl-TPE as a promising electrolyte for lithiumbattery application at $40{ }^{\circ} \mathrm{C}$, because of thermal stability up to $220{ }^{\circ} \mathrm{C}$, relatively high ionic conductivity at low temperature, fast $\mathrm{Li}^{+}$transport, suitable interface with lithium metal and electrochemical stability up to about $4 \mathrm{~V}$. Accordingly, the electrolyte composition herein proposed represents a good compromise in terms of thermal and electrochemical properties, expected to ensure enhanced performances in a temperature range below the typical melting point of PEO-based electrolytes, that is, about $60{ }^{\circ} \mathrm{C}$. Hence, the cl-TPE has been studied at 40 ${ }^{\circ} \mathrm{C}$ in a lithium cell employing $\mathrm{LiFePO}_{4}$ as the cathode (see Fig. 4). The cathode film, easily prepared by an environmentally-friendly aqueous process, was wet with a few drops of the LiFTFSI:Pyr ${ }_{1201}$ FTFSI electrolyte (molar ratio of 6:4) before full cell assembling in order to achieve good ionic conductivity within the porous electrode and improve the $\mathrm{LiFePO}_{4} /$ electrolyte interface (see the Experimental section for further details).

As mentioned in the Introduction, the high concentration of lithium salt may enhance the electrochemical performances of $\mathrm{Pyr}_{1201}$ FTFSI:LiFTFSI binary mixtures at relatively low temperature [29]. Fig. S2 in the Supplementary Information shows the galvanostatic cycling performances at $20^{\circ} \mathrm{C}$ of $\mathrm{Li} / \mathrm{LiFePO}_{4}$ cells using the $\mathrm{Pyr}_{1201}$ FTFSI:LiFTFSI solution with the 6:4 molar ratio. The cells exhibit stable cycling behavior, delivering a reversible capacity of about 120 and $150 \mathrm{mAh} \mathrm{g}^{-1}$ at $\mathrm{C} / 3$ and $\mathrm{C} / 10$ rates $\left(1 \mathrm{C}=170 \mathrm{~mA} \mathrm{~g}^{-1}\right)$ for 400 and 270 cycles, respectively. Minor lithium dendrites growth is observed only after 150 cycles at $\mathrm{C} / 3$ rate (see Fig. S2b). This issue is mitigated by decreasing the current to C/10 rate (see Fig. S2d). The cell employing the IL-LiFTFSI electrolyte, after a few-cycles activation [29], ensures reversible capacities ranging from 150 to $60 \mathrm{mAh} \mathrm{g}^{-1}$ upon the rate capability test from $\mathrm{C} / 10$ to $1 \mathrm{C}$ rate, 
fully recovering the initial capacity at $\mathrm{C} / 10$ rate after 50 cycles (see Fig. S2c). Accordingly, the $\mathrm{Li} / \mathrm{LiFePO}_{4}$ battery using the ternary, cross-linked PEO:Pyr ${ }_{1201}$ FTFSI:LiFTFSI electrolyte with high LiFTFSI concentration may provide good performances at relatively low temperature, as demonstrated by Fig. 4, and additionally benefit from the cross-linked, polymer configuration [26]. Indeed, the $\mathrm{Li} / \mathrm{cl}-\mathrm{TPE} / \mathrm{LiFePO}$ cell tested at $40{ }^{\circ} \mathrm{C}$ shows suitable behavior at $\mathrm{C} / 10$ rate $\left(1 \mathrm{C}=170 \mathrm{~mA} \mathrm{~g}^{-1}\right)$ in terms of voltage profiles (panel a) and cycling trend (panel b). The battery reversibly operates at about $3.4 \mathrm{~V}$ showing flat voltage profiles, according to the two-phase reaction of $\mathrm{LiFePO}_{4}$ [43] (see Fig. 4a), delivering a reversible capacity of about $150 \mathrm{mAh} \mathrm{g}^{-1}$ with a coulombic efficiency higher than $99.5 \%$, and a capacity fading to $130 \mathrm{mAh}$ $\mathrm{g}^{-1}$ at the $100^{\text {th }}$ cycle (see Fig. 4b). Furthermore, the cell exhibits capacity of $154,140,95,64$, and $48 \mathrm{mAh} \mathrm{g}^{-1}$ in a rate capability test at $\mathrm{C} / 20, \mathrm{C} / 10, \mathrm{C} / 5, \mathrm{C} / 3$, and $\mathrm{C} / 2$ rates $(1 \mathrm{C}=170 \mathrm{~mA}$ $\mathrm{g}^{-1}$ ), as shown by Fig. 4c. Fig. S3a in the Supplementary Information shows the voltage curves related to the rate capability test, revealing the expected polarization increase as the current rises. Panel d of Fig. 4 also reports the cycling behavior of a $\mathrm{Li} / \mathrm{cl}-\mathrm{TPE} / \mathrm{LiFePO}_{4}$ cell tested at $\mathrm{C} / 5$ rate upon 100 cycles with a CC-CV procedure (see the Experimental section and the related voltage profiles in Fig. S4b of the Supplementary Information for further details), which delivers about $85 \mathrm{mAh} \mathrm{g}^{-1}$ with a coulombic efficiency higher than $99.5 \%$. The Li/clTPE/ $\mathrm{LiFePO}_{4}$ cell ensures areal capacity of about 0.7 and $0.4 \mathrm{mAh} \mathrm{cm}{ }^{-2}$ at $\mathrm{C} / 10$ and $\mathrm{C} / 5$ rates, respectively, as shown in panel $\mathrm{b}$ and $\mathrm{d}$ of Fig. 4. It is worthy of mention that cycling tests of $\mathrm{Li} / \mathrm{LiFePO}_{4}$ cells employing the non-cross-linked TPE sample revealed lithium dendrite formation upon charge after few galvanostatic cycles, further confirming the beneficial effect of the cross-linking on the mechanical stability of cl-TPE materials (see Fig. S4 in the Supplementary Information).

\section{Figure 4}


The electrode/electrolyte interface stability of the $\mathrm{Li} / \mathrm{cl}-\mathrm{TPE} / \mathrm{LiFePO} 4$ cell upon cycling has been additionally investigated by EIS measurements. Fig. 5a shows the voltage profiles of the $1^{\text {st }}, 3^{\text {rd }}$ and $10^{\text {th }}$ cycles of a two-electrode $\mathrm{Li} / \mathrm{cl}-\mathrm{TPE} / \mathrm{LiFePO}_{4}$ cell cycled at $\mathrm{C} / 10$ rate $(1 \mathrm{C}=$ $170 \mathrm{~mA} \mathrm{~g}^{-1}$ ). Impedance spectra have been recorded at the open circuit voltage (OCV), at state of charge (SOC) of $25 \%$ and $100 \%$, as well as at state of discharge (SOD) of $25 \%$ and $100 \%$, as marked by circles in panel a. The related Nyquist plots, shown in panels b-e of Fig. 5, reveal the evolution of the overall resistance at the electrode/electrolyte interfaces $\left(\mathrm{R}_{\mathrm{T}}\right)$, which is ascribed to the anode and cathode contributions in series. Table S1 in the Supplementary Information reports the results of the NLLS analysis $[33,34]$ of the spectra in terms of $\mathrm{R}_{\mathrm{T}}$. Several phenomena, possibly having different time constants, are expected to contribute to the impedance response of the cell. Herein, we have employed an equivalent circuit formed by the arrangement in series of (i) a high-frequency ohmic electrolyte resistance, (ii) a high-middlefrequency sub-circuit formed by resistance and pseudo-capacitance elements in parallel, and (iii) a low-frequency pseudo-capacitance. Chi-square $\left(\chi^{2}\right)$ values of the order of $10^{-4}$ and low estimated errors on the calculated parameters confirm the reliability of the NLLS analysis (see Table S1 in the Supplementary Information). The impedance response slightly changes during cycling, revealing an additional contribution of a semicircle at medium frequency after 10 cycles. The attribution of each element to a specific phenomenon occurring in the cell is not unambiguous [44]. However, we can speculate that the high-middle frequency semicircles account for the processes at the electrode/electrolyte interfaces [45]. Accordingly, EIS reveals that $\mathrm{R}_{\mathrm{T}}$ at the voltage plateau (SOC and SOD of 25\%) slightly increases during cell operation and is as low as $35 \Omega \mathrm{cm}^{-2}$ after 10 cycles, thus suggesting fast charge transfer at the electrode/electrolyte interfaces.

\section{Figure 5}


The low values of $\mathrm{R}_{\mathrm{T}}$, which are comparable with those observed for conventional carbonate-based electrolytes [46], further confirm the suitability of the $\mathrm{Li} / \mathrm{cl}-\mathrm{TPE} / \mathrm{LiFePO} 4$ configuration at $40^{\circ} \mathrm{C}$. This working temperature may actually ensure reversible cycling at low current of the polymer cell. However, the poor performance at room temperature is still one of the main drawbacks hindering the widespread application of PEO-based electrolytes. Herein, we have performed a preliminary cycling test of the cl-TPE at $20{ }^{\circ} \mathrm{C}$ in $\mathrm{Li} / \mathrm{LiFePO}_{4}$ cell (see Fig. 6). The mass loading of $\mathrm{LiFePO}_{4}$ in the composite electrode has been decreased from 5.0 $\mathrm{mg} \mathrm{cm}{ }^{-2}$ (tests at $40{ }^{\circ} \mathrm{C}$ ) to $2.6 \mathrm{mg} \mathrm{cm}^{-2}$, in order to match the transport properties of the clTPE at $20^{\circ} \mathrm{C}$ (see Fig. 2a and the Experimental section for further details). Fig. 6a shows the voltage profiles of the $\mathrm{Li} / \mathrm{cl}-\mathrm{TPE} / \mathrm{LiFePO}_{4}$ cell cycled at $\mathrm{C} / 20$ and $\mathrm{C} / 10$ rates at $20{ }^{\circ} \mathrm{C}(1 \mathrm{C}=$ $170 \mathrm{~mA} \mathrm{~g}^{-1}$ ). Furthermore, we have enlarged the voltage window upon charge to $4 \mathrm{~V}$ to mitigate possible cell polarization increase at $20{ }^{\circ} \mathrm{C}$. Panel a reveals flat voltage plateaus centered at about $3.4 \mathrm{~V}$ with low polarization. The figure indicates profiles overlapping upon cycling, which suggest high reversibility of the electrochemical process, as well as slight cell activation in the initial 10 cycles likely related to slow cathode wetting at $20^{\circ} \mathrm{C}$. Such an initial increase of the capacity is clearly evident in Fig. 6b, reporting the cycling behavior at $\mathrm{C} / 10$ rate upon more than 100 cycles. The cell delivers reversible capacities of about $150 \mathrm{mAh} \mathrm{g}^{-1}$ and $130 \mathrm{mAh} \mathrm{g}^{-1}$ at $\mathrm{C} / 20$ and $\mathrm{C} / 10$ rates $\left(1 \mathrm{C}=170 \mathrm{~mA} \mathrm{~g}^{-1}\right)$ with coulombic efficiency higher than $99.5 \%$. The high coulombic efficiency values and relatively low capacity fading upon cycling suggests negligible electrolyte decomposition at $4 \mathrm{~V}$.

\section{Figure 6}

\section{Conclusion}

The ternary polymer electrolyte prepared by cross-linking a mixture of PEO, Pyr $_{1201}$ FTFSI and LiFTFSI in the 20:6:4 molar ratio in presence of the cross-linking agent (benzophenone) was investigated for application in lithium-metal cell. The electrolyte, stable 
up to $220^{\circ} \mathrm{C}$ as demonstrated by TGA, is expected to enhance the safety of the battery. A crosslinking procedure by benzophenone addition and UV irradiation, widely used to improve the amorphous fraction and the mechanical properties [27], prevented the crystallization upon cooling, as suggested by DSC. The ternary polymer electrolyte (cl-TPE) showed ionic conductivity ranging between $10^{-4} \mathrm{~S} \mathrm{~cm}^{-1}$ and $10^{-2} \mathrm{~S} \mathrm{~cm}^{-1}$ from 0 to $80{ }^{\circ} \mathrm{C}$. Hence, it was tested in lithium cells working at $40{ }^{\circ} \mathrm{C}$. At this temperature, the cl-TPE exhibited an ionic conductivity of $10^{-3} \mathrm{~S} \mathrm{~cm}^{-1}$, a limiting current density in lithium symmetrical cell of the order of $10^{-2} \mathrm{~mA} \mathrm{~cm}^{-2}$ and low interface resistance with lithium metal, which ensured reversible cycling in symmetrical lithium cell. The phospho-olivine cathode $\left(\mathrm{LiFePO}_{4}\right)$, matching the electrochemical stability window of the cl-TPE and characterized by remarkable thermal stability [47], was selected as the positive electrode to realize a lithium-metal, Li/clTPE/ $\mathrm{LiFePO}_{4}$ cell characterized by improved electrode/electrolyte interface, as demonstrated by EIS. The battery delivered a reversible capacity of about $150 \mathrm{mAh} \mathrm{g}^{-1}$ with respect to the cathode mass $\left(0.7 \mathrm{mAh} \mathrm{cm}^{-2}\right)$, with coulombic efficiency higher than $99.5 \%$ for 100 cycles at $\mathrm{C} / 10$ rate $\left(17 \mathrm{~mA} \mathrm{~g}^{-1}\right)$. Furthermore, preliminary cycling tests at $20{ }^{\circ} \mathrm{C}$ revealed promising results, that is, reversible capacity of $130 \mathrm{mAh} \mathrm{g}^{-1}$ for 100 cycles at $\mathrm{C} / 10$ rate $\left(17 \mathrm{~mA} \mathrm{~g}^{-1}\right)$ with coulombic efficiency higher than 99.5\%. Therefore, the PEO-Pyr ${ }_{1201}$ FTFSI-LiFTFSI membrane is considered as a suitable electrolyte for lithium-metal batteries.

\section{References}

[1] Q. Wang, P. Ping, X. Zhao, G. Chu, J. Sun, C. Chen, Thermal runaway caused fire and explosion of lithium ion battery, J. Power Sources. 208 (2012) 210-224. doi:10.1016/j.jpowsour.2012.02.038.

[2] P.G. Balakrishnan, R. Ramesh, T. Prem Kumar, Safety mechanisms in lithium-ion batteries, J. Power Sources. 155 (2006) 401-414. doi:10.1016/j.jpowsour.2005.12.002.

[3] V. Aravindan, Y.-S. Lee, S. Madhavi, Research Progress on Negative Electrodes for 
Practical Li-Ion Batteries: Beyond Carbonaceous Anodes, Adv. Energy Mater. 5 (2015) 1402225. doi:10.1002/aenm.201402225.

[4] J. Hassoun, B. Scrosati, Review-Advances in Anode and Electrolyte Materials for the Progress of Lithium-Ion and beyond Lithium-Ion Batteries, J. Electrochem. Soc. 162 (2015) A2582-A2588. doi:10.1149/2.0191514jes.

[5] D. Di Lecce, R. Verrelli, J. Hassoun, Lithium-ion batteries for sustainable energy storage: recent advances towards new cell configurations, Green Chem. 19 (2017) 34423467. doi:10.1039/C7GC01328K.

[6] W. Xu, J. Wang, F. Ding, X. Chen, E. Nasybulin, Y. Zhang, J.-G. Zhang, Lithium metal anodes for rechargeable batteries, Energy Environ. Sci. 7 (2014) 513-537. doi:10.1039/C3EE40795K.

[7] K. Zhang, G.H. Lee, M. Park, W. Li, Y.M. Kang, Recent Developments of the Lithium Metal Anode for Rechargeable Non-Aqueous Batteries, Adv. Energy Mater. 6 (2016) 1-14. doi:10.1002/aenm.201600811.

[8] L. Carbone, M. Gobet, J. Peng, M. Devany, B. Scrosati, S. Greenbaum, J. Hassoun, Polyethylene glycol dimethyl ether (PEGDME)-based electrolyte for lithium metal battery, J. Power Sources. 299 (2015) 460-464. doi:10.1016/j.jpowsour.2015.08.090.

[9] D. Di Lecce, L. Carbone, V. Gancitano, J. Hassoun, Rechargeable lithium battery using non-flammable electrolyte based on tetraethylene glycol dimethyl ether and olivine cathodes, J. Power Sources. 334 (2016) 146-153. doi:10.1016/j.jpowsour.2016.09.164.

[10] L. Carbone, D. Di Lecce, M. Gobet, S. Munoz, M. Devany, S. Greenbaum, J. Hassoun, Relevant Features of a Triethylene Glycol Dimethyl Ether-Based Electrolyte for Application in Lithium Battery, ACS Appl. Mater. Interfaces. 9 (2017) 17085-17095. doi:10.1021/acsami.7b03235.

[11] D. Di Girolamo, S. Panero, M.A. Navarra, J. Hassoun, Quaternary Polyethylene Oxide 
Electrolytes Containing Ionic Liquid for Lithium Polymer Battery, J. Electrochem. Soc. 163 (2016) A1175-A1180. doi:10.1149/2.0241607jes.

[12] G.A. Elia, U. Ulissi, F. Mueller, J. Reiter, N. Tsiouvaras, Y.-K. Sun, B. Scrosati, S. Passerini, J. Hassoun, A Long-Life Lithium Ion Battery with Enhanced Electrode/Electrolyte Interface by Using an Ionic Liquid Solution, Chem. - A Eur. J. 22 (2016) 6808-6814. doi:10.1002/chem.201505192.

[13] G.A. Elia, U. Ulissi, S. Jeong, S. Passerini, J. Hassoun, Exceptional long-life performance of lithium-ion batteries using ionic liquid-based electrolytes, Energy Environ. Sci. 9 (2016) 3210-3220. doi:10.1039/C6EE01295G.

[14] J. Hassoun, R. Verrelli, P. Reale, S. Panero, G. Mariotto, S. Greenbaum, B. Scrosati, A structural, spectroscopic and electrochemical study of a lithium ion conducting Li10GeP2S12 solid electrolyte, J. Power Sources. 229 (2013) 117-122. doi:10.1016/j.jpowsour.2012.11.130.

[15] M. Agostini, Y. Aihara, T. Yamada, B. Scrosati, J. Hassoun, A lithium-sulfur battery using a solid, glass-type P2S5-Li2S electrolyte, Solid State Ionics. 244 (2013) 48-51. doi:10.1016/j.ssi.2013.04.024.

[16] T. Yamada, S. Ito, R. Omoda, T. Watanabe, Y. Aihara, M. Agostini, U. Ulissi, J. Hassoun, B. Scrosati, All Solid-State Lithium-Sulfur Battery Using a Glass-Type P2S5Li2S Electrolyte: Benefits on Anode Kinetics, J. Electrochem. Soc. 162 (2015) A646A651. doi:10.1149/2.0441504jes.

[17] U. Ulissi, M. Agostini, S. Ito, Y. Aihara, J. Hassoun, All solid-state battery using layered oxide cathode, lithium-carbon composite anode and thio-LISICON electrolyte, Solid State Ionics. 296 (2016) 13-17. doi:10.1016/j.ssi.2016.08.014.

[18] A. Manuel Stephan, K.S. Nahm, Review on composite polymer electrolytes for lithium batteries, Polymer (Guildf). 47 (2006) 5952-5964. doi:10.1016/j.polymer.2006.05.069. 
[19] Z. Xue, D. He, X. Xie, Poly(ethylene oxide)-based electrolytes for lithium-ion batteries, J. Mater. Chem. A. 3 (2015) 19218-19253. doi:10.1039/C5TA03471J.

[20] F. Croce, G.B. Appetecchi, L. Persi, B. Scrosati, Nanocomposite polymer electrolytes for lithium batteries, Nature. 394 (1998) 456-458. doi:10.1038/28818.

[21] G.. Appetecchi, F. Croce, J. Hassoun, B. Scrosati, M. Salomon, F. Cassel, Hot-pressed, dry, composite, PEO-based electrolyte membranes, J. Power Sources. 114 (2003) 105112. doi:10.1016/S0378-7753(02)00543-8.

[22] Y.T. Kim, E.S. Smotkin, The effect of plasticizers on transport and electrochemical properties of PEO-based electrolytes for lithium rechargeable batteries, Solid State Ionics. 149 (2002) 29-37. doi:10.1016/S0167-2738(02)00130-3.

[23] J.-H. Shin, W. a. Henderson, S. Passerini, An Elegant Fix for Polymer Electrolytes, Electrochem. Solid-State Lett. 8 (2005) A125. doi:10.1149/1.1850387.

[24] J.-H. Shin, W. a. Henderson, S. Passerini, PEO-Based Polymer Electrolytes with Ionic Liquids and Their Use in Lithium Metal-Polymer Electrolyte Batteries, J. Electrochem. Soc. 152 (2005) A978. doi:10.1149/1.1890701.

[25] J.-H. Shin, W.A. Henderson, C. Tizzani, S. Passerini, S.-S. Jeong, K.-W. Kim, Characterization of Solvent-Free Polymer Electrolytes Consisting of Ternary PEOLiTFSI-PYR[sub 14] TFSI, J. Electrochem. Soc. 153 (2006) A1649. doi:10.1149/1.2211928.

[26] I. Osada, H. De Vries, B. Scrosati, S. Passerini, Ionic-Liquid-Based Polymer Electrolytes for Battery Applications, Angew. Chemie Int. Ed. 55 (2016) 500-513. doi:10.1002/anie.201504971.

[27] G.T. Kim, G.B. Appetecchi, M. Carewska, M. Joost, A. Balducci, M. Winter, S. Passerini, UV cross-linked, lithium-conducting ternary polymer electrolytes containing ionic liquids, J. Power Sources. $195 \quad$ (2010) 6130-6137. 
doi:10.1016/j.jpowsour.2009.10.079.

[28] M. Wetjen, G.-T. Kim, M. Joost, M. Winter, S. Passerini, Temperature dependence of electrochemical properties of cross-linked poly(ethylene oxide)-lithium bis(trifluoromethanesulfonyl)imide-N-butyl-N-methylpyrrolidinium bis(trifluoromethanesulfonyl)imide solid polymer electrolytes for lithium batteries, Electrochim. Acta. 87 (2013) 779-787. doi:10.1016/j.electacta.2012.09.034.

[29] G.A. Giffin, A. Moretti, S. Jeong, S. Passerini, Decoupling effective Li+ ion conductivity from electrolyte viscosity for improved room-temperature cell performance, $\quad$ J. $\quad$ Power $\quad$ Sources. $342 \quad$ (2017) 335-341. doi:10.1016/j.jpowsour.2016.12.071.

[30] G.B. Appetecchi, S. Scaccia, C. Tizzani, F. Alessandrini, S. Passerini, Synthesis of Hydrophobic Ionic Liquids for Electrochemical Applications, J. Electrochem. Soc. 153 (2006) A1685. doi:10.1149/1.2213420.

[31] M. Montanino, F. Alessandrini, S. Passerini, G.B. Appetecchi, Water-based synthesis of hydrophobic ionic liquids for high-energy electrochemical devices, Electrochim. Acta. 96 (2013) 124-133. doi:10.1016/j.electacta.2013.02.082.

[32] V. Sharova, G.-T. Kim, G.A. Giffin, A. Lex-Balducci, S. Passerini, Quaternary Polymer Electrolytes Containing an Ionic Liquid and a Ceramic Filler., Macromol. Rapid Commun. (2016) 1-6. doi:10.1002/marc.201600025.

[33] B. Boukamp, A package for impedance/admittance data analysis, Solid State Ionics. 1819 (1986) 136-140. doi:10.1016/0167-2738(86)90100-1.

[34] B.A. Boukamp, A Nonlinear Least Squares Fit procedure for analysis of immittance data of electrochemical systems, Solid State Ionics. 20 (1986) 31-44. doi:10.1016/01672738(86)90031-7.

[35] P. Meister, V. Siozios, J. Reiter, S. Klamor, S. Rothermel, O. Fromm, H.W. Meyer, M. 
Winter, T. Placke, Dual-ion cells based on the electrochemical intercalation of asymmetric fluorosulfonyl-(trifluoromethanesulfonyl) imide anions into graphite, Electrochim. Acta. 130 (2014) 625-633. doi:10.1016/j.electacta.2014.03.070.

[36] G.G. Eshetu, T. Diemant, S. Grugeon, R.J. Behm, S. Laruelle, M. Armand, S. Passerini, In-Depth Interfacial Chemistry and Reactivity Focused Investigation of Lithium-Imideand Lithium-Imidazole-Based Electrolytes, ACS Appl. Mater. Interfaces. 8 (2016) 16087-16100. doi:10.1021/acsami.6b04406.

[37] E. Simonetti, M. Carewska, G. Maresca, M. De Francesco, G.B. Appetecchi, Highly Conductive, Ionic Liquid-Based Polymer Electrolytes, J. Electrochem. Soc. 164 (2017) A6213-A6219. doi:10.1149/2.0331701jes.

[38] M. Joost, G.T. Kim, M. Winter, S. Passerini, Phase stability of Li-ion conductive, ternary solid polymer electrolytes, Electrochim. Acta. $113 \quad$ (2013) 181-185. doi:10.1016/j.electacta.2013.09.052.

[39] M. Wetjen, M.A. Navarra, S. Panero, S. Passerini, B. Scrosati, J. Hassoun, Composite poly(ethylene oxide) electrolytes plasticized by N-alkyl-N-butylpyrrolidinium bis(trifluoromethanesulfonyl)imide for lithium batteries, ChemSusChem. 6 (2013) 1037-1043. doi:10.1002/cssc.201300105.

[40] A.K. Padhi, Phospho-olivines as Positive-Electrode Materials for Rechargeable Lithium Batteries, J. Electrochem. Soc. 144 (1997) 1188. doi:10.1149/1.1837571.

[41] G.T. Kim, G.B. Appetecchi, F. Alessandrini, S. Passerini, Solvent-free, PYR1ATFSI ionic liquid-based ternary polymer electrolyte systems. I. Electrochemical $\begin{array}{llllll}\text { characterization, } & \text { J. } & \text { Power } & \text { Sources. } & 171 & \text { (2007) }\end{array}$ doi:10.1016/j.jpowsour.2007.07.020.

[42] M. Wetjen, G.T. Kim, M. Joost, G.B. Appetecchi, M. Winter, S. Passerini, Thermal and electrochemical properties of PEO-LiTFSI-Pyr 14TFSI-based composite cathodes, 
incorporating 4 V-class cathode active materials, J. Power Sources. 246 (2014) 846857. doi:10.1016/j.jpowsour.2013.08.037.

[43] D. Di Lecce, J. Hassoun, Lithium Transport Properties in LiMn 1- $\alpha$ Fe $\alpha$ PO 4 Olivine Cathodes, J. Phys. Chem. C. 119 (2015) 20855-20863. doi:10.1021/acs.jpcc.5b06727.

[44] M. Gaberscek, J. Moskon, B. Erjavec, R. Dominko, J. Jamnik, The Importance of Interphase Contacts in Li Ion Electrodes: The Meaning of the High-Frequency Impedance Arc, Electrochem. Solid-State Lett. 11 (2008) A170. doi:10.1149/1.2964220.

[45] M. Ender, A. Weber, E. Ivers-Tiffée, Analysis of Three-Electrode Setups for ACImpedance Measurements on Lithium-Ion Cells by FEM simulations, J. Electrochem. Soc. 159 (2012) A128. doi:10.1149/2.100202jes.

[46] D. Di Lecce, R. Verrelli, J. Hassoun, New lithium ion batteries exploiting conversion/alloying anode and $\mathrm{LiFe} 0.25 \mathrm{Mn} 0.5 \mathrm{Co} 0.25 \mathrm{PO} 4$ olivine cathode, Electrochim. Acta. 220 (2016) 384-390. doi:10.1016/j.electacta.2016.10.067.

[47] D. Di Lecce, C. Fasciani, B. Scrosati, J. Hassoun, A Gel-Polymer Sn-C/LiMn 0.5 Fe 0.5 PO 4 Battery Using a Fluorine-Free Salt, ACS Appl. Mater. Interfaces. 7 (2015) 21198-21207. doi:10.1021/acsami.5b05179. 


\section{Figure captions}

Figure 1. Thermal characterization of the TPE (blue) and cl-TPE (green) samples. (a) TGA under an $\mathrm{N}_{2}$ flow $\left(40 \mathrm{~mL} \mathrm{~min}{ }^{-1}\right)$ at a heating rate of $5^{\circ} \mathrm{C} \min ^{-1}$ from 30 to $600{ }^{\circ} \mathrm{C}$; mass percent on the left $y$-axis (continuous line) and derivative curve on the right y-axis (dashed line). (b) Cooling and (c) heating scans of DSC in an $\mathrm{N}_{2}$ atmosphere at a rate of $10{ }^{\circ} \mathrm{C} \mathrm{min}^{-1}$; the samples were cycled between $50{ }^{\circ} \mathrm{C}$ and $-140{ }^{\circ} \mathrm{C}$ at $10{ }^{\circ} \mathrm{C} \mathrm{min}^{-1}$ before performing the measurement.

Figure 2. Electrochemical properties of the cl-TPE. (a) Ionic conductivity by EIS measurements on a $\mathrm{Cu} / \mathrm{cl}-\mathrm{TPE} / \mathrm{Cu}$ pouch cell at several temperatures; each spectrum was recorded after $24 \mathrm{~h}$ of temperature equilibration upon heating and cooling scans. (b) Limiting current density measured at $40{ }^{\circ} \mathrm{C}$ by linear sweep voltammetry at a scan rate of $0.01 \mathrm{mV} \mathrm{s}^{-1}$ of a $\mathrm{Li} / \mathrm{cl}-\mathrm{TPE} / \mathrm{Li}$ coin cell. (c) Anodic stability window as determined by linear sweep voltammetry at a scan rate of $0.1 \mathrm{mV} \mathrm{s}^{-1}$ of a coin cell using lithium as the counter electrode and carbon-coated $\mathrm{Al}$ as the working electrode (see the Experimental section for further details).

Figure 3. Electrochemical properties at $40{ }^{\circ} \mathrm{C}$ of the Li/cl-TPE interface. (a) Interface resistance $\left(\mathrm{R}_{\mathrm{i}}\right)$ determined by EIS measurements on a Li/cl-TPEs/Li coin cell during storage for 30 days; Ri has been calculated by NLLS analysis [33,34] of the EIS data (Nyquist plots and equivalent circuit in figure inset). (b) Lithium stripping/plating test of a $\mathrm{Li} / \mathrm{cl}-\mathrm{TPE} / \mathrm{Li}$ coin cell cycled at $100 \mu \mathrm{A} \mathrm{cm}^{-2}$ ( step time $\left.=1 \mathrm{~h}\right)$.

Figure 4. Cycling performances at $40{ }^{\circ} \mathrm{C}$ of the $\mathrm{Li} / \mathrm{cl}-\mathrm{TPE} / \mathrm{LiFePO}_{4}$ cell. Galvanostatic cycling at $\mathrm{C} / 10$ rate $\left(1 \mathrm{C}=170 \mathrm{~mA} \mathrm{~g}^{-1}\right)$ within the $2-3.9 \mathrm{~V}$ range in terms of (a) voltage profiles and (b) cycling behavior (discharge capacity on the left y-axes expressed as gravimetric and areal values; coulombic efficiency in the right y-axis). (c) Rate capability test at $\mathrm{C} / 20, \mathrm{C} / 10, \mathrm{C} / 5, \mathrm{C} / 3$, and $\mathrm{C} / 2$ rates $\left(1 \mathrm{C}=170 \mathrm{~mA} \mathrm{~g}^{-1}\right)$ within the $2-3.9 \mathrm{~V}$ range in terms 
of cycling behavior (related voltage profiles in Fig. S3a of the Supplementary Information). (d) Cycling behavior at $\mathrm{C} / 5$ rate $\left(1 \mathrm{C}=170 \mathrm{~mA} \mathrm{~g}^{-1}\right)$ within the $2-3.7 \mathrm{~V}$ range with a $\mathrm{CV}$ step at the end of charge (current limit for the CV step of $\mathrm{C} / 20$ rate; discharge capacity on the left $y$-axes expressed as gravimetric and areal values; coulombic efficiency in the right $y$-axis; related voltage profiles in Fig. S3b of the Supplementary Information). Electrodes loading = $5.0 \pm 0.3 \mathrm{mg}_{\mathrm{LiFePO}_{4}} \mathrm{~cm}^{-2}$.

Figure 5. EIS measurements of the $\mathrm{Li} / \mathrm{cl}-\mathrm{TPE} / \mathrm{LiFePO}_{4}$ cell upon galvanostatic cycling at $\mathrm{C} / 10$ rate $\left(1 \mathrm{C}=170 \mathrm{~mA} \mathrm{~g}^{-1}\right)$ within the $2-3.9 \mathrm{~V}$ range. (a) Voltage profiles of the $1^{\text {st }}, 3^{\text {rd }}$ and $10^{\text {th }}$ cycles (positions corresponding to the EIS experiments marked by circles). (b) Nyquist plots related to EIS tests recorded at (e) OCV, SOC of (b) 25\% and (c) 100\%, and SOD of (d) $25 \%$ and (e) $100 \%$. Temperature $=40{ }^{\circ} \mathrm{C}$.

Figure 6. Cycling performances at $20{ }^{\circ} \mathrm{C}$ of the $\mathrm{Li} / \mathrm{cl}-\mathrm{TPE} / \mathrm{LiFePO} 4$ cell within the $2-$ $4 \mathrm{~V}$ range in terms of (a) voltage profiles at $\mathrm{C} / 20$ and $\mathrm{C} / 10$ rates and (b) cycling behavior at $\mathrm{C} / 10$ rate $\left(1 \mathrm{C}=170 \mathrm{mAh}^{-1}\right.$; discharge capacity on the left $\mathrm{y}$-axis; coulombic efficiency in the right y-axis). Electrode loading $=2.6 \pm 0.1 \mathrm{mg}_{\mathrm{LiFePO}_{4}} \mathrm{~cm}^{-2}$. 

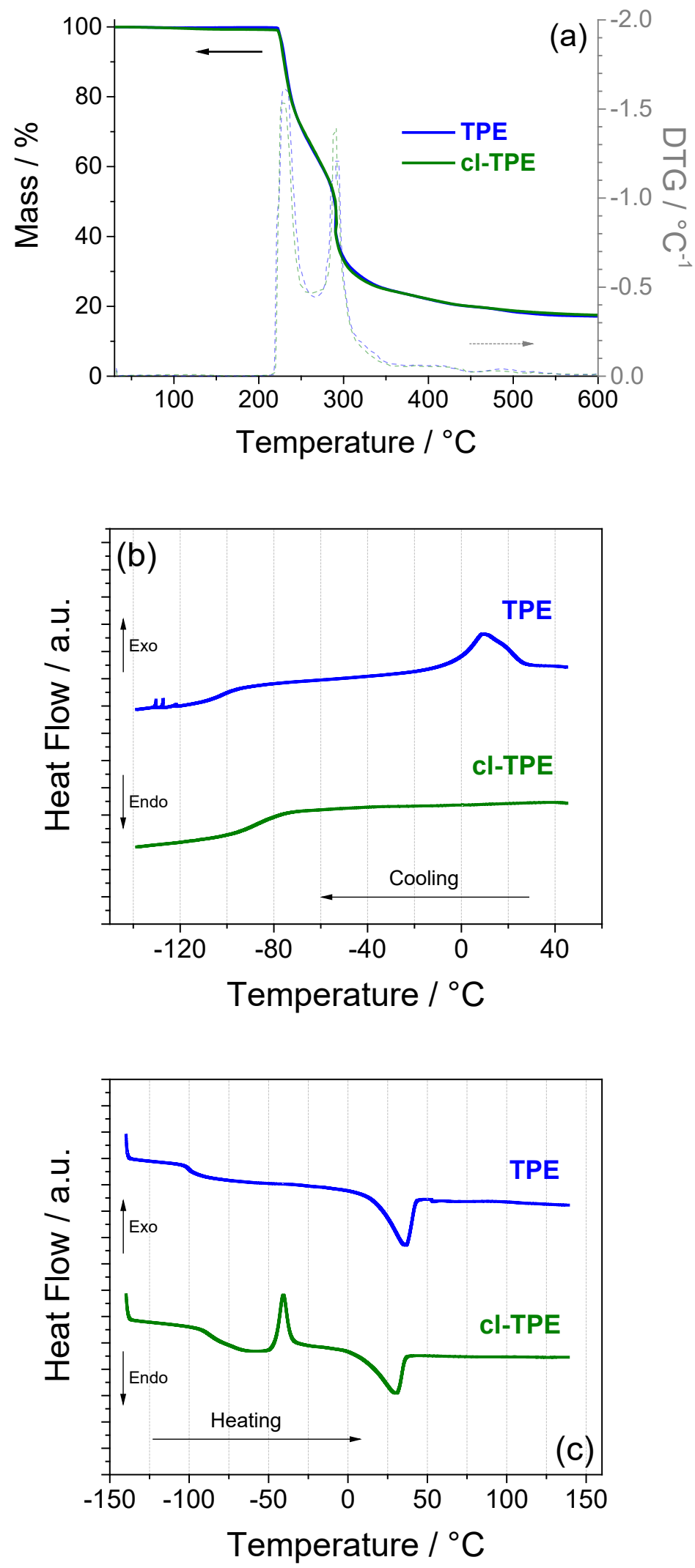

Figure 1 
Temperature $/{ }^{\circ} \mathrm{C}$
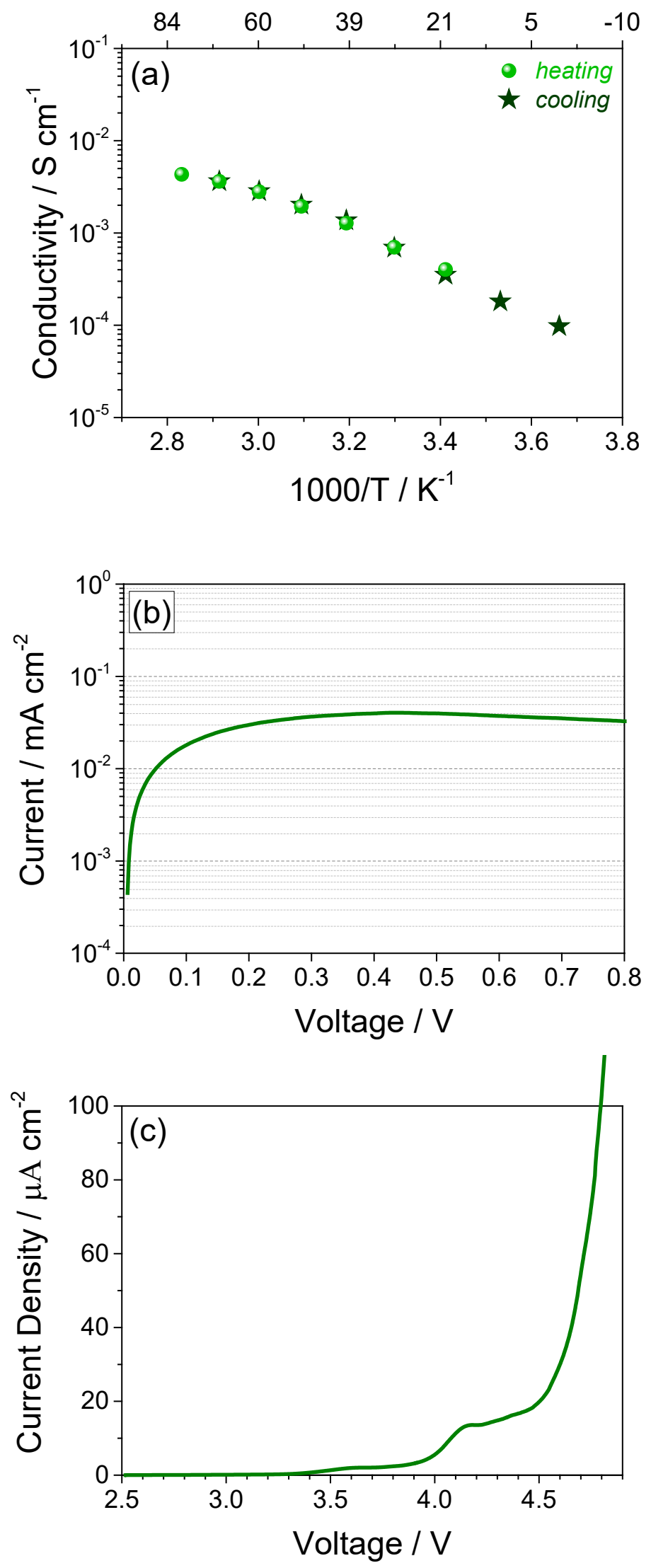

Figure 2 

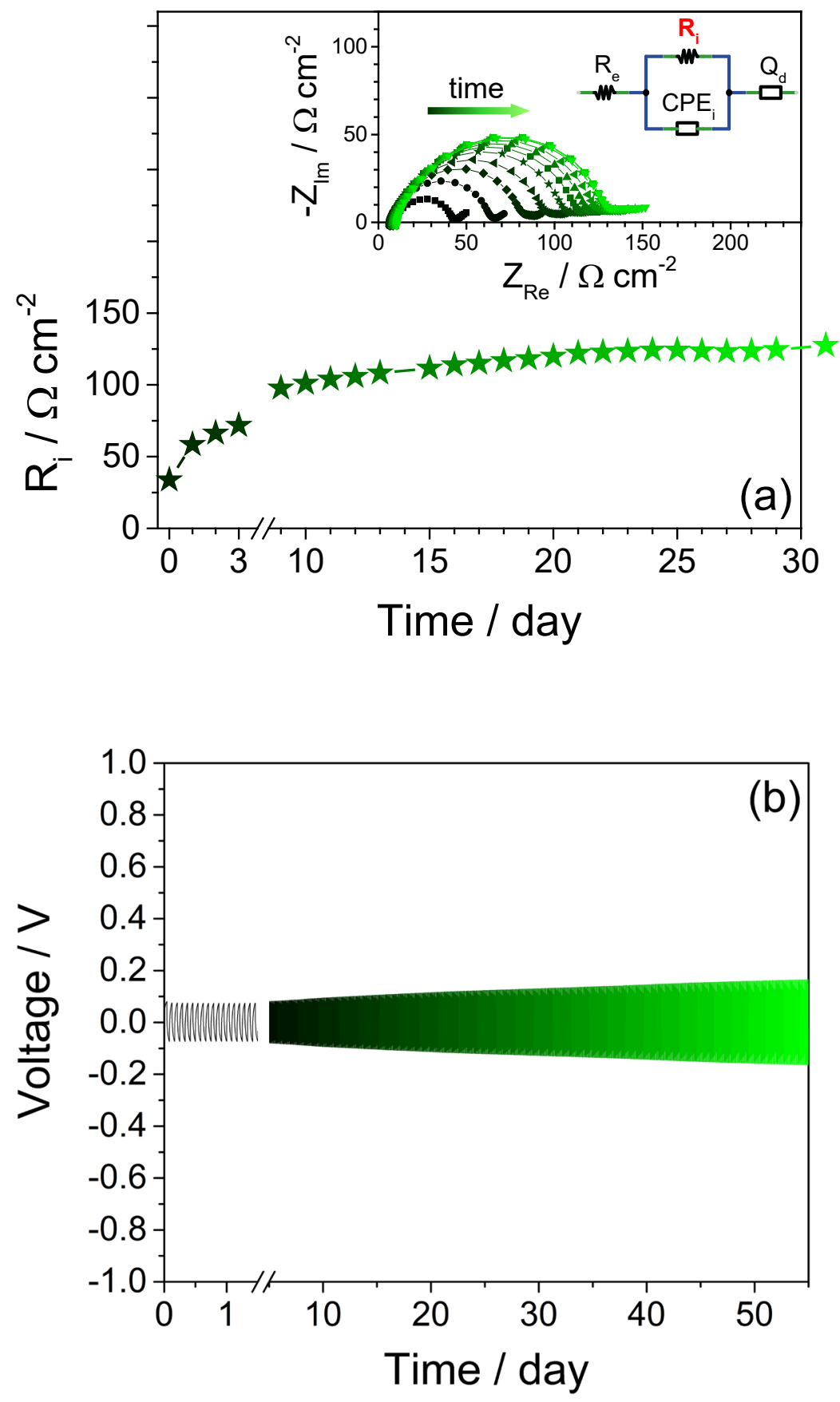

Figure 3 

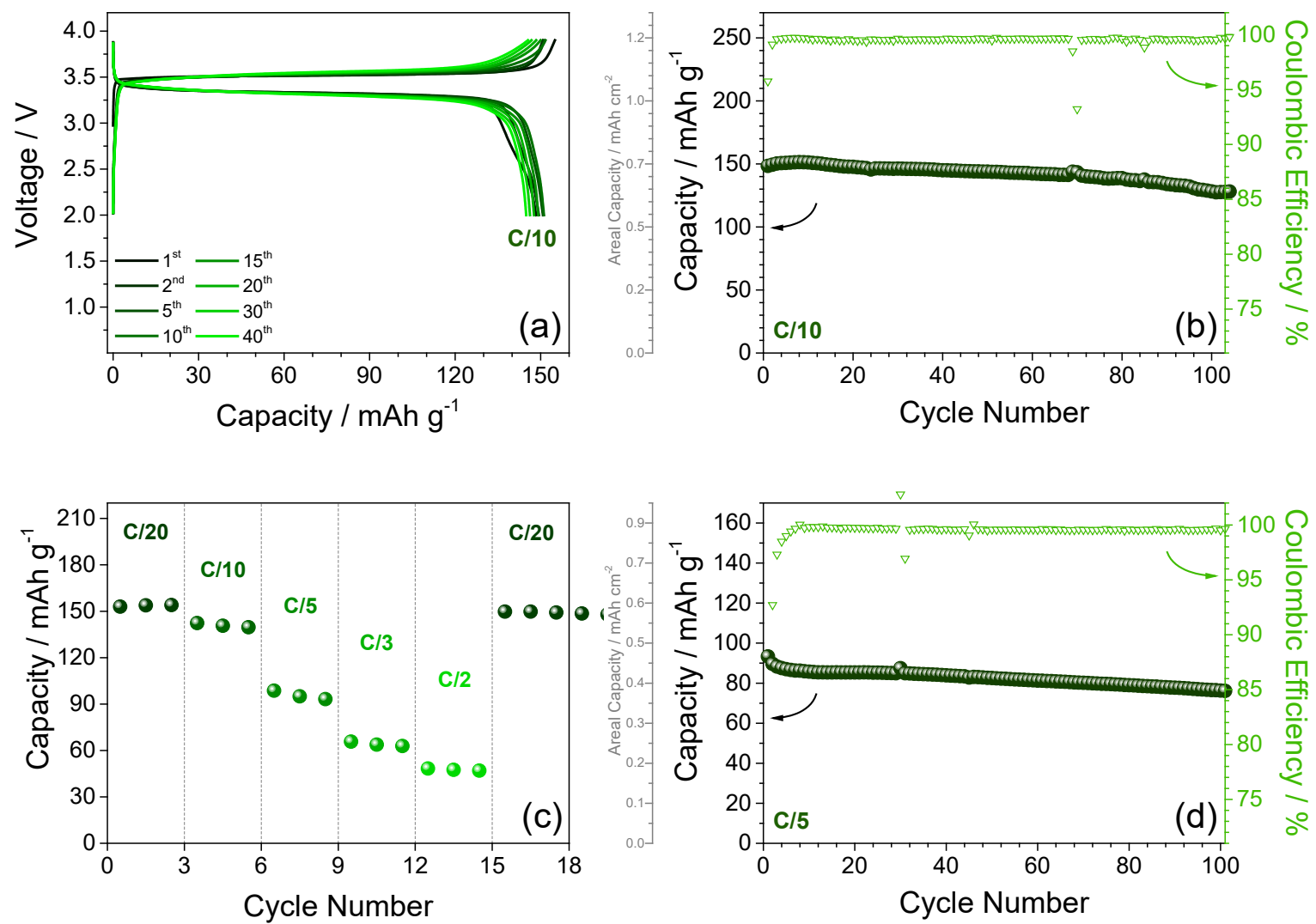

Figure 4 


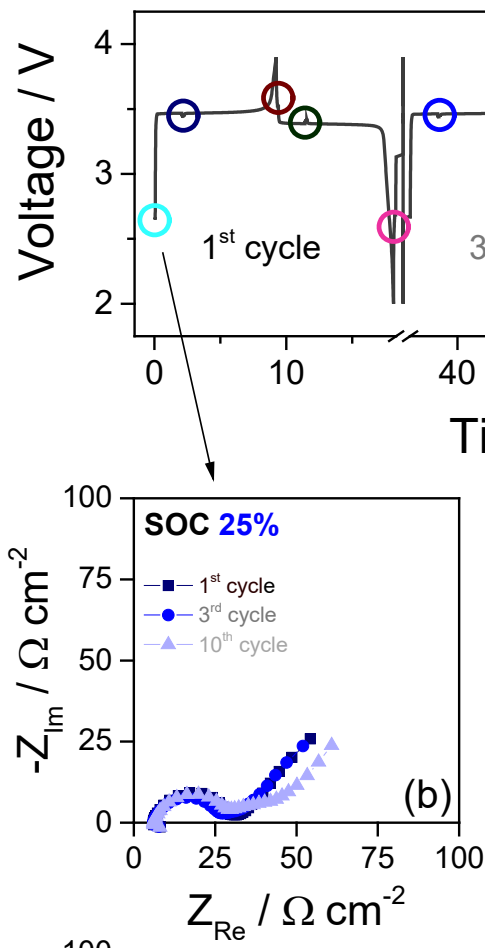

(a)
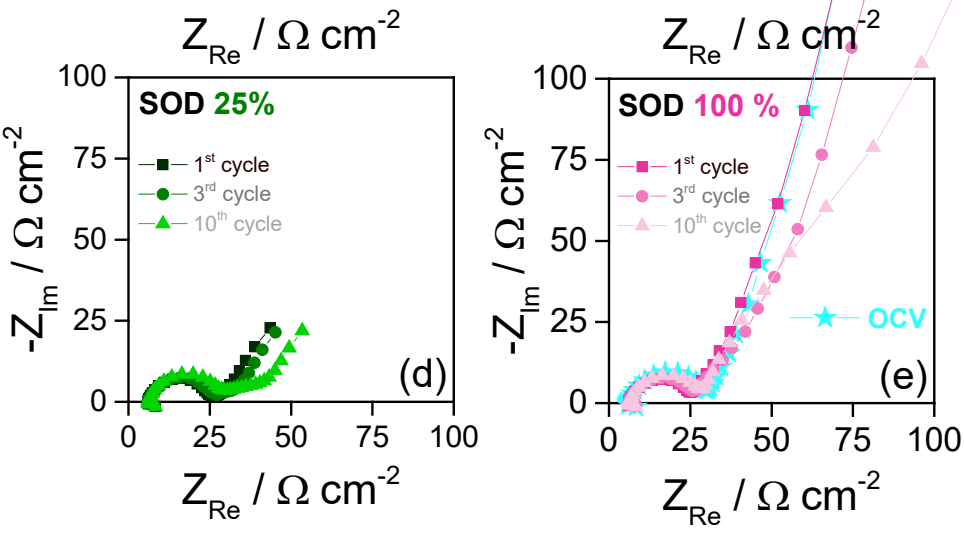

Figure 5 

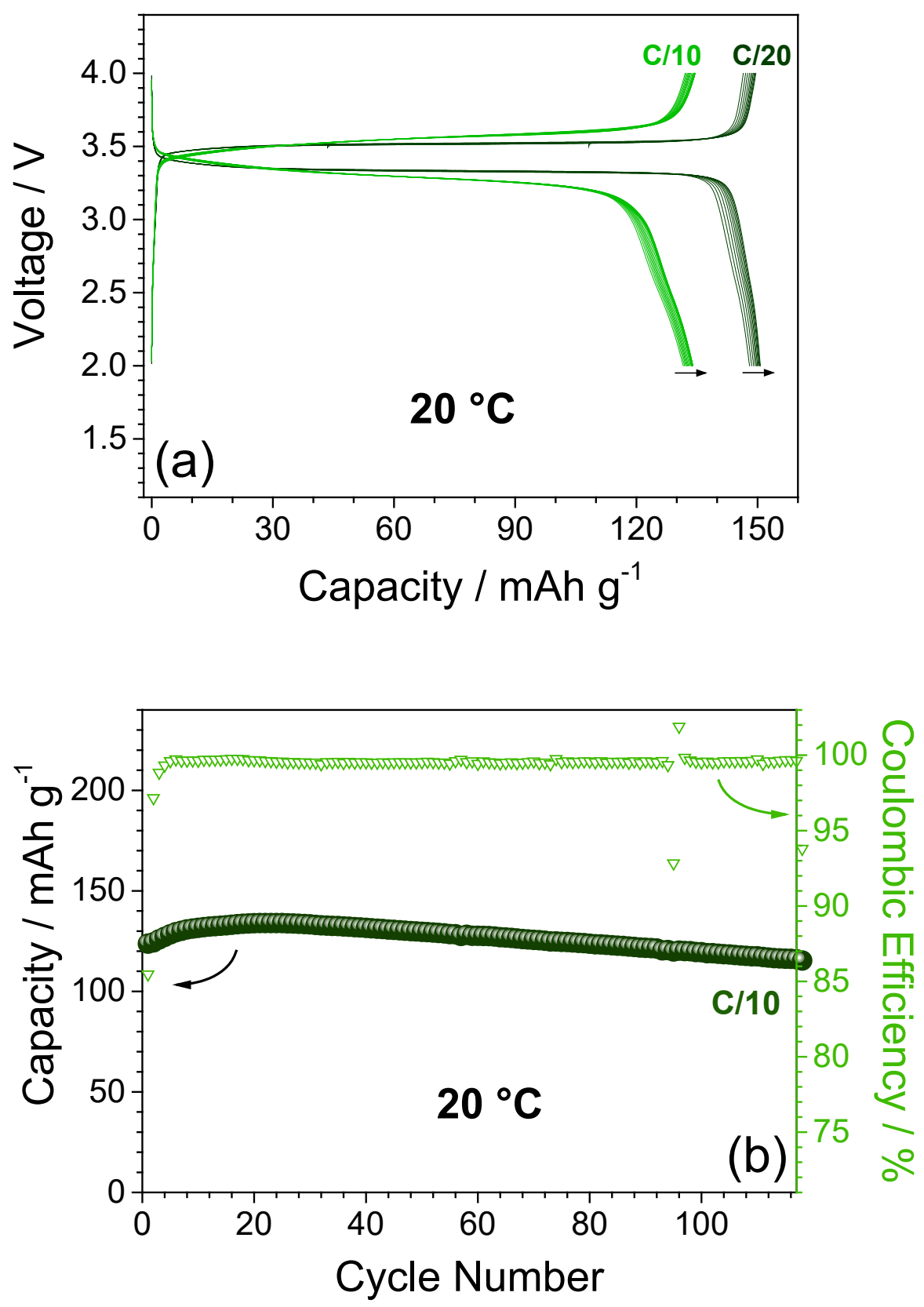

Figure 6 


\section{Graphical Abstract}

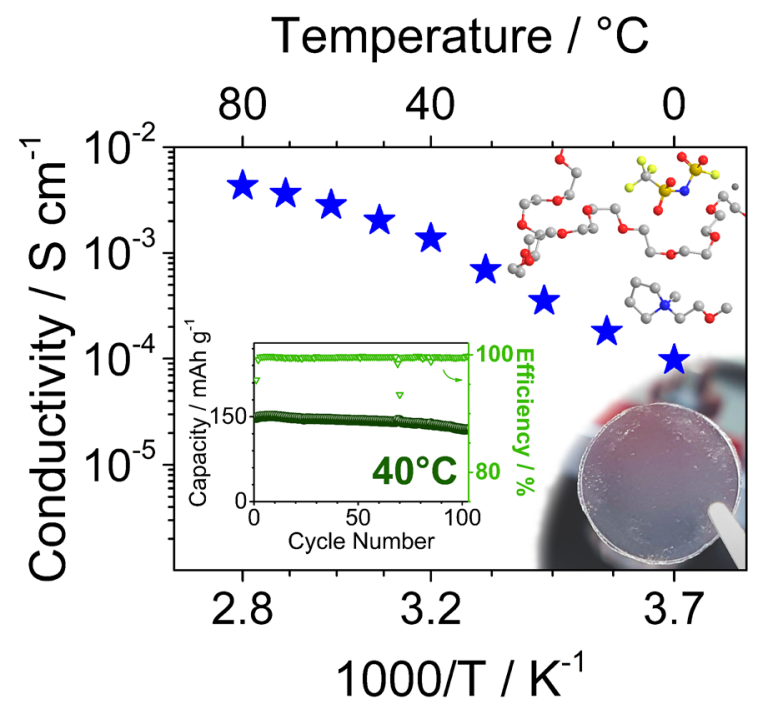

